\title{
Molecular Variations among some Isolates of Fusarium oxysporum f.sp lycopersici and Response of Different Tomato Cultivars and Seedling Age to Infection
}

O.I. Saleh*; M.R. Gabr*; M.A. Khalil** and

E.I. Mohamed**

* Plant Pathol. Dept., Fac. Agric. El-Minia Unv., Egypt.

** Plant Pathol. Res. Inst., Agric. Res. Centre, Giza, Egypt.

\begin{abstract}
Qurvey of tomato wilt was carried out through two successive growing seasons (2013 and 2014) in farms' located at 4 sites belonging to four Egyptian Governorates (Behera, Minofiya, Ismailia and Minia). The disease incidence in these sites ranged between 14.3 in Ismailia Governorate and $37.5 \%$ in Minofiya Governorate. Isolation on Potato Agar medium from naturally infected plants collected from some Egyptian Governorates resulted in obtaining many fungal isolates that proved to be pathogenic to tomato Super-Strain B cultivar on pathogenicity test.The agent responsible for wilt of tomato in Egypt was identified as Fusarium oxysporum. The pathogenic capabilities of eight fungal isolates representing different localities in different Governorates, i.e. Behera, Minofiya, Ismailia and Minia were investigated., Pathogenicity test using eight isolates of Fusarium oxysporum isolated from naturally infected tomato plants showing typical symptoms of wilt revealed that they were all able to cause wilt symptoms on different tomato cultivars. In this respect, isolate of F. oxysporum isolated from El-Khatatba, Minofiya Governorate was the most virulent that induced the disease in tomato plants. Ten plant species were evaluated for their reactions to infection with the most virulent isolate, El-Khattba (Minofiya Governorate). The RAPD-PCR of the DNA analysis using 10-mer primer of eight isolates of $F$. oxysporum f.sp. lycopersici collected from different Governorates showed variations in DNA pattern. To test their response to infection with this isolate, ten tomato cultivars were evaluated to infection by the most virulent isolate (isolated from El-Khattba, Minofiya Governorate) and the results indicated that cv. Super-Strain B was the highest susceptible, whereas cv. Super-Marmand was the lowest one. Moreover, effect of tomato seedlings age of Super-Strain B (highly susceptible) and Super-Marmand (low susceptible) on infection by the most virulent isolate of the pathogen was tested.
\end{abstract}

Keywords: Fusarium oxysporum f.sp. lycopersici, host range, RAPDPCR analysis, seedling age and tomato cultivars.

Tomato (lycopersicon esculentum Mill) is one of the most worldwide grown vegetables (Amini, 2009 and Hamini-Kadar et al., 2014). Unfortunately, the plant is subject to many diseases caused by fungi, bacteria, viruses and nematodes that cause severe losses in yield (Nusret and Steven, 2004; Amini, 2009 and BaharMorid et al., 2012). Fusarium wilt of tomato caused by F. oxysporum f.sp. lycopersici (Sacc.) 
Snyder \& Hansen is one of the most prevalent, destructive diseases worldwide that affect yield and quality (Reis et al., 2005). In Egypt, Awad (1990) reported that infection by $F$. oxysporum f.sp. lycopersici sometimes is the main reason for restriction of expanding tomato area and also increasing production costs. The crop is highly affected during the seasons of early spring and autumn in Governorates of Upper Egypt and the newly reclaimed sandy regions of Nubaria and Ismailia.

Identification of Fusarium species can be achieved by their morphological characteristics on selective media (Burgress et al., 1994). However, the pathogenic types or formae specials and races cannot be identified by morphological characteristics. Three known physiological races (1,2 and 3) of $F$. oxysporum f.sp. lycopersici are distinguished by their specific pathogenicity on different known cultivars carrying dominant race specific resistant genes (Masunaga et al., 1998 and Sammour et al., 2013). Race 1 and 2 of F. oxysporum f.sp. lycopersici have been reported in most tomato growing regions of the world (Reis et al., 2005). Recently many molecular techniques are used as practical and reliable methods for identification of fungi. Molecular markers are accurate and useful tools to identify formae specials and races of $F$. oxysporum f.sp. lycopersici (Livens et al., 2008). Pathogenicity of different isolated fungi was also performed. Some based on polymerase chain reaction (PCR), and includes random amplified polymorphic DNA, amplified fragment length polymorphism, simple sequence repeats and sequence related amplified polymorphism (Geiser et al., 2004; Al-Khatib et al., 2006; Hirano and Aris, 2006 and Jacobs et al., 2013). In Japan differentiation of $F$. oxysporum f.sp. lycopersici and $F$. oxysporum f.sp. radicis-lycopersic has been achieved by polymerase chain reaction PCR-based method using specific primer sets developed due to knowledge of the partial nucleotide sequences of the endopolygalacturnases genes endo (pg1) and exopolygalacturnases genes of ( $\mathrm{pg} \times 4)$ of fungi (Hirano and Aris, 2006).

Tomato cultivars and hybrids reacted variably to Fusarium infection race1, 2 and 3 (Al-Khatib et al., 2006; Hirano and Aris, 2006 and Irzykowska et al., 2012). Moreover, these authors added that race 1 and 2 are distributed worldwide whereas, race 3 has limited geographical distribution (Hirano and Aris, 2006).

Infection with Fusarium wilt fungus is affected considerably with seedlings age and the ability of the plant to tolerate or even overcome infection (Gamal El-din et al., 1982, Scott and Jones, 1989 and Al-Khatib et al., 2006). The present investigation was conducted to isolate and identify the causative agent of Fusarium wilt of tomato. Plant species were evaluated for their susceptibility to infection by the most virulent isolate. Moreover, RAPD-PCR analysis on the isolated fungi was also achieved to show variation in DNA patterns. Finally, reaction of different varieties to infection by the isolated fungus and effect of plant age were studied.

\section{Materials and Methods}

1. Occurrence of tomato wilt in four Egyptian Governorates:

Survey of tomato wilt was carried out through early spring and autumn plantations during two successive seasons, i.e. 2013 and 2014 in four Egyptian 
Governorates, i.e. Behera, Minofiya, Ismailia and Minia. Percentages of disease incidence were calculated from randomly chosen fields located at the previously mentioned Governorates. Disease incidence was calculated as the following formula: Disease incidence $(\%)=($ No. of plants showing wilt symptoms/Total No. of inspected plants) $\mathbf{x} 100$.

2. Isolation and identification of fungi associated wilted tomato plants:

Isolation trials were carried out from naturally infected tomato plants by wilt collected from locations belonging to 4 Egyptian Governorates, i.e. Behera, Minofiya, Ismailia and Minia. Roots and stems of diseased plants were thoroughly washed under running tap water to remove all adherent soil particles. Diseased materials were cut into small pieces $(0.5 \mathrm{~cm})$ and surface sterilized using $1 \%$ sodium hypochlorite for 2 minutes then washed several times in sterilized distilled water. The pieces were dried between folds of sterilized filter paper then transferred onto the surface of potato sucrose agar medium containing streptomycin $(25 \mu \mathrm{g} / \mathrm{ml})$ in Petri-dishes. Plates were incubated at $25^{\circ} \mathrm{C}$ for 3 days. The emerged fungi were picked-up, purified using the hyphal tip and/or single spore techniques adopted by Dhingra and Sinclair (1995). The purified fungal isolates were identified according to the keys given by Gilman (1957) and Nelson et al. (1983) as Fusarium oxysporum.

\section{Pathological studies:}

3.A. Pathogenicity test using eight isolates of Fusarium oxysporum under greenhouse conditions:

Pathogenic ability of eight isolates of $F$. oxysporum, previously isolated and identified from naturally infected tomato plants, to induce wilt in tomato plants was evaluated under greenhouse conditions. The fungal isolates were grown separately on autoclaved sorghum grain sand medium $(100 \mathrm{~g}$, washed dried sorghum grains, $100 \mathrm{~g}$, washed dried coarse sand and $65 \mathrm{ml}$, tap water per bottle) in $500 \mathrm{ml}$ glass bottles. Inoculation was carried out using uniform agar discs $(5 \mathrm{~mm}$. diam.) bearing 4 days old fungal growth of any of the tested isolates. The bottles were incubated at $28^{\circ} \mathrm{C}$ for two weeks to obtain sufficient growth of the fungal isolates.

Fertile soil was taken from the surface layer of soil of the experimental farm; Faculty of Agric. Minia Univ. and was sterilized using formalin solution (5\%). Formalin disinfested clay pots $(30$-cm-diam.) were filled with sterilized soil at the rate of $3 \mathrm{~kg} /$ pot. The potted soil was then artificially infested with the desired inoculum prepared at the rate of $3 \%(\mathrm{w} / \mathrm{w})$, then watered two times during one week before planting. In check treatments, equal amounts of uninoculated substrate were added in pots (Gabr et al., 1998).Tomato seedlings (cv. Super-Strain B) grown for 30 days in seed boxes filled with autoclaved peat-moss vermiculite $(1: 1 \mathrm{w} / \mathrm{w})$ were uprooted and transplanted in the pots at the rate of 3 seedlings/pot. Four replicate pots were used for each fungal isolate. Pots were irrigated directly after transplanting and subsequently as when necessary.

Disease assessment:

At 30 days after transplanting the following assessments were calculated: 
Disease index of foliar browning:

Disease severity of foliar yellowing was determined by rating each leaf on the severity of wilt symptoms and yellowing according to 0-4 scale and computing the average grade for plant as a whole according to the following formula: $\%$ of foliar yellowing $=$ (Sum of foliar yellowing value $/(4 \mathrm{x}$ Total number of leaf) $\mathrm{x} 100$ (ElZawahry, 1984;Fakhouri and Buchenaure, 2003 and Song et al., 2004). In the present study, the following numerical grades were used:

$0=$ Healthy plants.

$1=1$-less than $25 \%$ of plant leaflets are yellow (slight chlorosis, wilting or stunting).

$2=25$-less than $50 \%$ of plant leaflets are yellow(moderate chlorosis, wilting or stunting).

$3=50$-less than $75 \%$ of plant leaflets are yellow (severe chlorosis, wilting or stunting).

$4=75$ - less than $100 \%$ of plant leaflets are yellow (very severe chlorosis, complete wilting or dead plant).

Disease index of vascular browning:

Disease index of vascular browning was determined by estimating the internal discoloration (browning) area of vascular bundle by making longitudinal and transverse section of root according to the scale described by (Gothoskar et al., 1953).

$0=$ no brown discoloration in vascular bundles of root and the crown and stem.

$1=1$-less than $25 \%$ of vascular root bundles are brown.

$2=25$ - less than $50 \%$ of vascular root bundles are brown.

$3=50$ - less than $75 \%$ of vascular root bundles are brown.

$4=75$ - less than $100 \%$ of vascular root bundles are brown.

The percentage of internal discoloration was calculated following the formula: $\%$ of vascular browning $=($ Sum of vascular browning values/ (4xTotal number of plants) $\mathrm{x} 100$.

3.B. Host range of F. oxysporum using the most virulent isolate:

This experiment was carried out under greenhouse conditions using the highly pathogenic isolate of $F$. oxysporum, the most virulent (isolated from El-Khatatba, Minofiya Governorate) causing severe tomato wilt incidence for testing its ability to induce wilt on other plant species belonging to different families (Rowe, 1980). Ten plant species belonging to families, solanaceae, cucurbitaceae, leguminosae, chenopodiaceae and gramineae were tested in addition to plant species, i.e. pepper (Capsicum frutescens L.) Elpaso hybrid, eggplant (Solanum melongena var. Esculentum Nees) Hanen hyb, chillies (Capsicums sp.) Cayenne Lang Slim hyb.Jimsonweed (Datura stramonium var. linne), potato (Solonum tuberosum) cv. Kara, petunia (Petunia hybrida), cucumber (Cucumis sativus L.) Novo hyb, soybean (Glycine max L. Merr) cv. Giza 22, sugar beet (Beta vulgaris L.) cv. Gloria and wheat (Triticum aestivum L.) cv. Giza 164. Again some species of the following families were used to differentiate between $F$. oxysporum f.sp. lycopersici and $F$. oxysporum f.sp. radicis-lycopersici (Jarvis and Showoemaker, 1978; Rowe, 1980; Bahar-Morid et al., 2012 and Boix-Ruiz et al., 2015), cucurbitaceae (cucumber), leguminosae (soybean), chenopodiaceae (sugar beet) and gramineae (wheat). 
Inoculum preparation, soil infested and assessment of disease incidence were carried out 60 days after sowing as mentioned before under pathogenicity test. Seeds and grains were surface sterilized as mentioned before and sown in artificially infested soil. Control treatments were used but without inocula, plants were observed daily for development of disease symptoms.

3.C. RAPD-PCR analysis of genetic variation among isolates of F. oxysporum f.sp. lycopersici isolated from naturally infected tomato plants:

This experiment was carried out in the laboratory of Agricultural Research Centre (ARC), Ministry of Agriculture. Isolates of F. oxysporum f.sp. lycopersici, the causal of Fusarium wilt of tomato were grown in $50 \mathrm{ml}$ potato broth in conical flasks for 15 days at $28^{\circ} \mathrm{C}$.

Fungal growth on duplex media:

Petri dishes were used instead of liquid shacked cultures to grow the different fungal isolates for DNA isolation. Disposable polystyrene Petri dishes $(4 \mathrm{~cm})$ contained $1800 \mu \mathrm{L}$ solid medium (potato dextrose agar), to which a layer of liquid medium (1400 $\mu \mathrm{L}$ peptone yeast glucose) was added. The fungal isolates were cultured by inoculating a small loop from stock onto the medium prepared in Petri dishes that were subsequently incubated at $28^{\circ} \mathrm{C}$ for $2-3$ days. Mycelium was harvested from the medium using sterilized inoculating loops then transferred into sterile $1.5-\mathrm{mL}$ microcenterfuge tubes. Fungal cells were pelleted by centrifugation for $15 \mathrm{~min}$ at $4000 \mathrm{rpm}$ a deep well swing-bucket rotor (microcenrifuge5804 R; Eppendorf). The mycelium pellet was washed with $600 \mathrm{mLTE}$ (Triesedita) buffers and centrifuged again for $5 \mathrm{~min}$ at $4000 \mathrm{rpm}$ and finally; TE (Triesedita) buffer was decanted.

\section{DNA extraction:}

A modification of the traditional sodium dodecyl sulphate (SDS) extraction procedure was adopted. Fresh fungal pellets were homogenized in $400 \mu \mathrm{L}$ sterile salt in homogenizing buffer (200 mMTrise-HCl, pH8.5, $250 \mathrm{mMNaCl}, 25 \mathrm{mM}$ EDITA, $0.5 \%$ SDS). Next, $6 \mu \mathrm{L} 20 \mathrm{mg} / \mathrm{mL}$ RNase A were added and mixed thoroughly. The samples were incubated at $65^{\circ} \mathrm{C}$ for $10 \mathrm{~min}$, after which $130 \mu \mathrm{L} 3 \mathrm{M}$ sodium acetate, $\mathrm{pH} 5.2$, were added to each sample. Samples were vortexed for 30 second at maximum speed, when incubated at $20^{\circ} \mathrm{C}$ for $10 \mathrm{~min}$. The lysate was centrifuged at $13,000 \mathrm{rpm}$ at $4^{\circ} \mathrm{C}$ for $15 \mathrm{~min}$, and the supernatant was transferred into fresh tubes. An equal volume of isopropanol was added to each sample, and mixed well, and samples were incubated at $-20^{\circ} \mathrm{C}$ for $10 \mathrm{~min}$. Samples were then centrifuged at 6000 rpm for $20 \mathrm{~min}$ at $4^{\circ} \mathrm{C}$. The DNA pellets were washed twice using $700 \mu \mathrm{L}$ washing solution (100 and 70\% ethanol, respectively). The DNA pellets were subsequently air dried in an oven at $40^{\circ} \mathrm{C}$ for at least $10 \mathrm{~min}$. The resultant DNA pellet was then re-suspended in $100 \mu \mathrm{L} 1 \mathrm{XTE}(10 \mathrm{mMTrise}-\mathrm{HCl}, 1 \mathrm{mM}$ EDITA) buffer, $\mathrm{pH} 8.0$ (Abd-Elsalam et al., 2007).

DNA quantification and gel documentation:

Seven microliters of the isolated DNA and $3 \mu \mathrm{L}$ of $10 \times$ loading dye were loaded in a lane of $1.5 \%(\mathrm{w} / \mathrm{v})$ agarose gel containing $0.05 \mu \mathrm{g} / \mathrm{ml}$ ethidium bromide, to check the quality of the DNA. For quantitative measurements, a charge-coupled 
device camera imaging system and UVIsoft analysis (Gel Documentation and Analysis Systems, Uvitec, Cambridge, UK) were used to capture the image and to calculate the band intensities.

\section{RAPD-PCR analysis:}

Analysis was performed in $25-\mu \mathrm{l}$ reaction volumes containing PCR buffer (Promega, Mannheim, Germany), 0.2 RAPD-PCR, analysis was undertaken using 10-mer primer (MWG, Germany). RAPD mmol/1 dNTPs, $0.5 \mathrm{mmol} / 1$ primer (5-d AATCGGGCTG-3), 4.0 mmol/1 MgCl2, 1.25 units of Taq Polymerase (Promega, Mannheim, Germany) and 10-20 ng genomic DNA. PCR reactions were carried out in a T-Gradient thermal cycler (Biometra, Germany) using the following profile: 94 ${ }^{\circ} \mathrm{C}$ for $1 \mathrm{~min}, 36^{\circ} \mathrm{C}$ for $1 \mathrm{~min}$ and $72^{\circ} \mathrm{C}$ for $1 \mathrm{~min}$ for 30 cycles, and a final extension at $72{ }^{\circ} \mathrm{C}$ for $5 \mathrm{~min}$. Following amplification, the samples were separated by electrophoresis in $1.4 \%$ agarose gel, stained with $0.5 \mu \mathrm{g} / \mathrm{ml}$ of ethidium bromide and viewed under ultra-violet light. A 300-to 1500-bp ladder (Promega, Mannheim, Germany) was used as a molecular mass marker.

3.D. Evaluation of ten different tomato cultivars to infection by the most pathogenic isolate of F. oxysporum f.sp. lycopersici:

Seedlings of ten tomato cultivars namely; Super-Strain B, Prichard, Peto 95, Fayrose, Super-Magic, Yara, Super-Balady, Super-Shahd, Marmand and SuperMarmand were tested for their response to infection by the most pathogenic isolate of $F$. oxysporum f.sp. lycopersici under greenhouse conditions. Healthy, thirty days old seedlings of the aforementioned tomato cultivars were transplanted in pots 30 $\mathrm{cm}$ containing soil already infested with the pathogenic isolate as previously mentioned. Four seedlings were sown in each pot and four replicate pots were used for each cultivar. Transplants were irrigated directly and subsequently when necessary and as recommended. Seedlings were observed daily and disease severity was recorded after 30 days of transplanting as previously described under pathogenicity test.

3.E. Effect of tomato seedling age on the infection by the most pathogenic isolate of F. oxysporum f.sp. lycopersici:

This experiment was carried out under greenhouse conditions to study the susceptibility of tomato seedlings of different ages to infection by the most pathogenic isolate of $F$. oxysporum f.sp. lycopersici. In this respect, susceptible tomato cultivar (Super-Strain B) and the resistant one (Super-Marmand) were used. Four tomato seedlings aging, 20, 25, 30 and 40 days old, representing any tested cultivar were evaluated to infection by the pathogenic isolate. Seedlings of four ages of the two aforementioned tomato cultivars were transplanted in sterilized pots (30$\mathrm{cm}$ diameter) previously inoculated as mentioned under pathogenicity test. All agricultural practices and procedures were carried out as recommended. Results were taken after 30 days of transplanting as mentioned before.

Statistical analysis:

Data were subjected to statistical analysis of variance. The experimental design (S) of all studies was a completely randomized with three replications, analysis of variance (ANOVA) of the data was performed with the MSTAT-C statistical package (A) micro-computer program for the design, management, and analysis of 
agronomic research experiments. Michigan State Univ., USA. Least significant difference (LSD) was used to compare treatment means (Gomez and Gomez, 1984).

\section{R e s u l t s}

1. Occurrence of tomato wilt disease in four Egyptian Governorates:

Field observations of randomly chosen tomato fields located at four Egyptian Governorates showed that naturally infected plants were suffered from leaf chlorosis, epinasty, drooping of leaves and the whole plants exhibited different degrees of wilt symptoms. Moreover, when the diseased plants were split longitudinally they showed different degrees of browning in roots and stem base. In most surveyed fields, diseased plants developed chlorosis, epinasty and clear wilt symptoms. The natural infection percentages varied in different surveyed Governorates as well as in the two successive sampling years. Generally, percentage of infection ranged from $14.3-37.5 \%$ on the average (Table, 1). However, infection of tomato plants in fields of Minofiya Governorate was higher than any of the other inspected Governorates through the two successive seasons, being $37.5 \%$ on the average. However, the lowest average percentage of infection by the disease was recorded from Ismailia Governorate $(14.3 \%)$.

Table 1. Occurrence of tomato Fusarium wilt at the different surveyed Governorates during seasons 2013 and 2014

\begin{tabular}{|l|c|c|c|}
\hline \multirow{2}{*}{ Governorate } & \multicolumn{2}{|c|}{ Disease incidence (\%) } & \multirow{2}{*}{ Mean } \\
\cline { 2 - 3 } & Season 2013 & Season 2014 & 18.0 \\
\hline Behera & 17.9 & 18.1 & 37.5 \\
\hline Minofiya & 39.3 & 35.7 & 14.3 \\
\hline Ismailia & 14.3 & 14.3 & 23.2 \\
\hline Minia & 25.0 & 21.4 & - \\
\hline Mean & 24.1 & 22.4 & \\
\hline L.S.D at $0.05 \%$ & 13.33 & 10.93 & \\
\hline
\end{tabular}

2. Isolation and identification of fungi associated with wilted tomato plants:

Isolation from diseased tomato plants showing wilt symptoms showed that. Fusarium sp. found to be associated with wilted tomato plants under investigation. Preliminary identification of the obtained isolates based on cultural, morphological characteristics and microscopic examinations according to Gilman (1957); Barnet and Hunter (1972); Booth, 1985 and Burgress et al. (1994) revealed that the isolated fungal isolates were $F$. oxysporum. Subsequently identification was confirmed by Assuit University Mycological Institute (AUMI). Fungal isolates isolated on PDA grew at $25^{\circ} \mathrm{C}$. The culture changed in colour from white peach, salmon and purple to violet. The mycelium was striate, felted to floccose and sometimes wrinkled in older cultures (three weeks). The microconidia are oval-ellipsoid, cylindrical, straight or curved, from 5 to $12 \mu \mathrm{m}$ by 2.2 to $3.5 \mu \mathrm{m}$ and are produced from short simple phialides arising laterally on the hyphae or from short sparsely branched conidiophores. The macroconidia are produced sparsely and are borne on elaborately branched conidiophores. They are generally thin-walled and pointed at both ends; three-septate spore ranging in size from 27 to $46 \mu \mathrm{m}$ by 3 to $4.5 \mu \mathrm{m}$. 
Chlamydospores are most commonly found, generally found and formed singly or in pairs intercalary or terminally.

Data in Table (2) indicate that fungi belonging to four genera were isolated from farms located at four Egyptian Governorates, Behera, Minofiya, Ismailia and Minia. Fusarium oxysporum was the most prevalent as constituted $26.7 \%$ in Minofiya, followed by Alternaria alternata. Aspergillus niger and Trichoderma harzianum that were also isolated but at lower frequencies, respectively. These results are in harmony with those reported from Egypt and other parts of the world (Kordali and Demirci 1998; Pushpa et al., 1999; Yan et al., 2004 and Mohamed, 2007).

Table 2. Occurrence and frequency (\%) of fungi isolated from tomato plants collected from four different Governorates

\begin{tabular}{|l|l|c|}
\hline Governorate & Isolated fungus & Frequency (\%) $^{*}$ \\
\hline \multirow{4}{*}{ Behera } & Fusarium oxysporum & 20.0 \\
\cline { 2 - 3 } & Alternaria alternata & 15.0 \\
\cline { 2 - 3 } & Aspergillus niger & 3.3 \\
\cline { 2 - 3 } & Trichoderma harzianum & 1.7 \\
\hline \multirow{4}{*}{ Minofiya } & Fusarium oxysporum & 26.7 \\
\cline { 2 - 3 } & Alternaria alternata & 20.0 \\
\cline { 2 - 3 } & Aspergillus niger & 20.0 \\
\cline { 2 - 3 } & Trichoderma harzianum & 8.3 \\
\hline \multirow{4}{*}{ Minia } & Fusarium oxysporum & 21.7 \\
\cline { 2 - 3 } & Alternaria alternata & 16.7 \\
\cline { 2 - 3 } & Aspergillus niger & 6.7 \\
\cline { 2 - 3 } & Trichoderma harzianum & 3.3 \\
\hline & Fusarium oxysporum & 23.3 \\
\cline { 2 - 3 } & Alternaria alternata & 18.3 \\
\cline { 2 - 3 } & Aspergillus niger & 10.0 \\
\cline { 2 - 3 } & Trichoderma harzianum & 220.0 \\
\hline
\end{tabular}

* Frequency $(\%)=$ Number of the isolated isolates $\mathrm{x} 100 /$ Total number of the isolated fungi

3. Pathological studies:

3.a. Pathogenicity test using the eight isolates of F. oxysporum:

In this experiment eight fungal isolates of $F$. oxysporum isolated from different localities belonging to four different Governorates were tested for their ability to infect tomato plants. Data of the pathogenicity test (Table, 3) indicate that all isolates of $F$. oxysporum isolated from naturally wilted tomato plants produced the symptoms of Fusarium wilt expressed as leaves epinasty associated with foliar yellowing and browning of the vascular bundle on cv. Super-Strain B tomato cultivar. Isolate of $F$. oxysporum isolated from El-khatatba (Minofiya Governorate) produced the highest percentage of foliar yellowing and wilt $(57.2 \%)$ which was significantly higher than any of the tested isolates followed by isolate of Behdal (44.1\%) and isolate of Derwa, (27.2\%). On the other hand, infection with the remainder of the isolates from different Governorates ranged from moderately to weakly. Regarding the vascular browning produced by the tested fungal isolates, the 
same trend was obtained with that of foliar yellowing and wilts (Table, 3). Moreover, reisolation from artificially inoculated plants resulted in obtaining the originally isolated fungi proving Koch's postulates.

Table 3. Pathogenicity test of $F$. oxysporum isolates on tomato Super-Strain B cultivar under greenhouse conditions

\begin{tabular}{|c|c|c|c|}
\hline \multirow[b]{2}{*}{ Fungal source } & \multirow[b]{2}{*}{ locality } & \multicolumn{2}{|c|}{ Disease severity (\%) } \\
\hline & & $\begin{array}{c}\text { Foliar yellowing and } \\
\text { wilt }(\%)\end{array}$ & $\begin{array}{c}\text { Vascular } \\
\text { browning (\%) }\end{array}$ \\
\hline Behera & Housh-essa & 22.7 & 32.1 \\
\hline \multirow{3}{*}{ Minofiya } & Sheben El-koam & 15.5 & 31.3 \\
\hline & Berket El-sabaa & 10.2 & 17.1 \\
\hline & El-khatatba & 57.2 & 66.3 \\
\hline Ismailia & El-kassasen & 19.9 & 29.0 \\
\hline \multirow{3}{*}{ Minia } & Derwa & 27.2 & 35.2 \\
\hline & Mallawy & 24.6 & 36.5 \\
\hline & Behdal & 44.1 & 49.6 \\
\hline \multicolumn{2}{|l|}{ Control } & 0.0 & 0.0 \\
\hline \multicolumn{2}{|l|}{ Mean } & 24.6 & 33.0 \\
\hline \multicolumn{2}{|l|}{ L.S.D at $0.05 \%$} & 14.11 & 19.35 \\
\hline
\end{tabular}

\section{3.b. Host range of F. oxysporum:}

Data in Table (4) show that the tested fungus infected some plant species belonging to the family solanaceae with varying degrees when these plant species were sown in artificially infested soil with the fungal inocula. Artificially infected species included pepper (Capsicum frutescens L.), eggplant (Solanum melongena var. Esculentum Nees), chillies (Capsicums sp), Jimsonweed (Datura stramonium var. linne), potato (Solanum tuberosum) and petunia (Petunia hybrida). Some plant species responded positively and produced wilt symptoms ranged from 7.0 to $40.9 \%$. High disease severity was recorded in pepper $(40.9 \%)$ followed by eggplant, potato and jimsonweed. Low disease severity was recorded on chillies and petunia, being 24.0 and $7.0 \%$, respectively. On the other hand, other plant species belonging to cucurbitaceae, i.e. cucumber (Cucumis sativus L.), leguminosae, i.e. soybean (Glycine max L.Merr), chenopodiaceae, i.e. sugar beet (Beta vulgaris L.) and Graminae, i.e. wheat (Triticum aestivum L.) were not infected. Disease symptoms recorded on solanaceae species were yellowing, epinasty, drooping, losing turgidity of the leaves. Discoloration of vascular bundle was also observed on the previously mentioned hosts. The highest vascular browning percentage (58.0\%) was also recorded from pepper plants followed by eggplant, being $49.3 \%$. No crown rot and root rot symptoms were recorded suggesting the isolate under investigation belongs to F. oxysporum f.sp. lycopersici.

3.c. RAPD-PCR analysis of genetic variation among isolates of F. oxysporum f.sp. lycopersici isolated from naturally infected tomato plants:

The obtained results (Figs 1 and 2) obviously show dendrogram derived from RAPD-PCR. It is clear that there was similarity among DNA of the pathogenic isolates of $F$. oxysporum f.sp. lycopersici isolated from different localities. This similarity level was 85.43 among the tested isolates. However, dendrogram indicated 
that these isolates can be divided into 5 main groups, i.e. group1 that had similarity level accounted $98.70 \%$ and included two isolates from El-Khatatba No.1 and Berket El-sabaa No.3, (Minofiya Governorate). The second group had similarity

Table 4. Host range of $F$. oxysporum El-khatatba isolate

\begin{tabular}{|c|c|c|c|}
\hline \multicolumn{2}{|r|}{ Tested plant species } & \multicolumn{2}{|c|}{ Disease severity (\%) } \\
\hline $\begin{array}{l}\text { English } \\
\text { name }\end{array}$ & Scientific name & $\begin{array}{c}\text { Foliar } \\
\text { yellowing } \\
\text { and wilt }(\%) \\
\end{array}$ & $\begin{array}{c}\text { Vascular } \\
\text { browning } \\
(\%)\end{array}$ \\
\hline Pepper & Capsicum frutescens $\mathrm{L}$ & 40.9 & 58.0 \\
\hline Eggplant & Solanum melongena var. Esculentum Nees & 34.4 & 49.3 \\
\hline Potato & Solonum tuberosum & 30.1 & 35.8 \\
\hline Chillies & Capsicums sp & 24.0 & 28.5 \\
\hline Datura & Datura stramonium var. linne & 25.7 & 29.5 \\
\hline Petunia & Petunia hybrida & 7.0 & 6.1 \\
\hline Cucumber & Cucumis sativus L. & 0.0 & 0.0 \\
\hline Soybean & Glycine max L.Merr & 0.0 & 0.0 \\
\hline sugar beet & Beta vulgaris L. & 0.0 & 0.0 \\
\hline Wheat & Triticum aestivum $\mathrm{L}$. & 0.0 & 0.0 \\
\hline \multicolumn{2}{|l|}{ Control } & 0.00 & 0.00 \\
\hline \multicolumn{2}{|c|}{ L.S.D at $0.05 \%$} & 7.55 & 13.31 \\
\hline
\end{tabular}

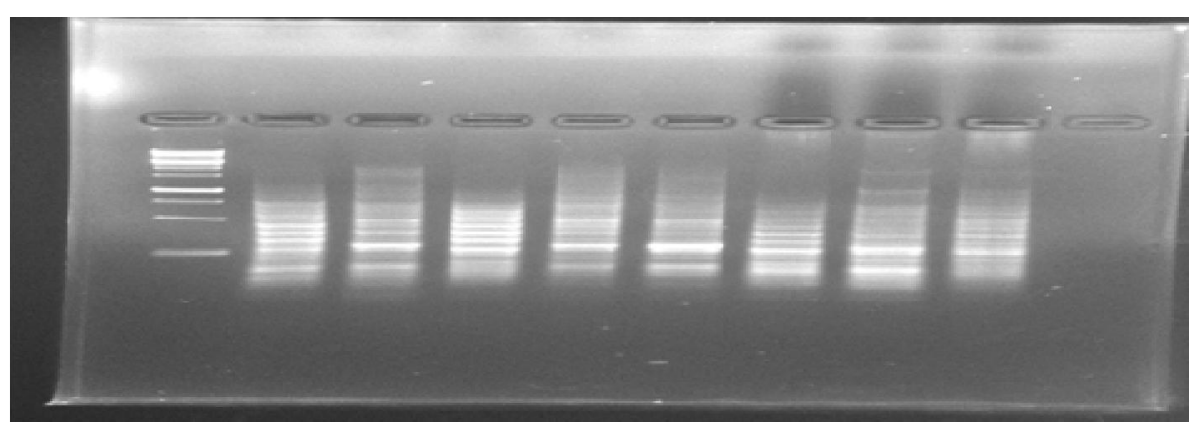

Fig. 1. RAPD analysis of DNA performed on eight isolates of $F$. oxysporum f.sp. lycopersici.

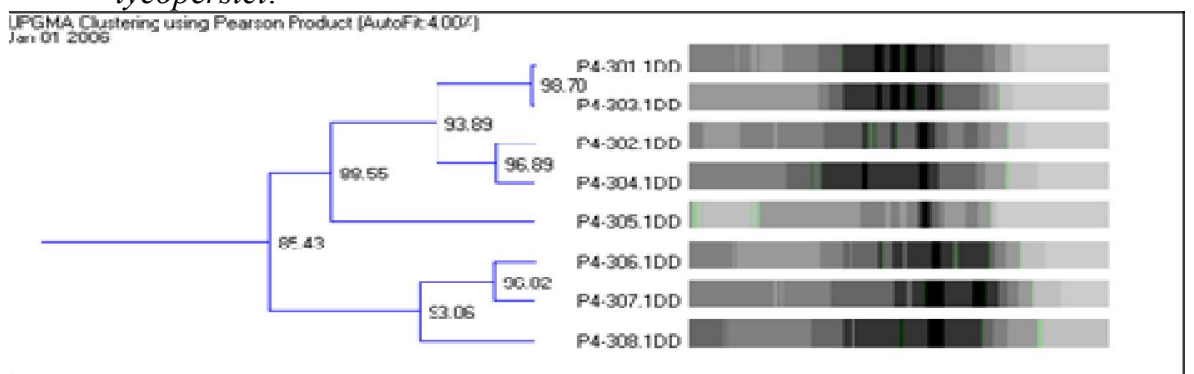

Fig. 2. Dendrogram derived from RAPD (Randdom amplified polymorphic DNA) profile analysis of eight isolates of $F$. oxysporum f.sp. lycopersici. 
level 96.89\% and included isolates No.2 from Sheben El-koam, (Minofiya Governorate) and isolate No.4 from Derwa, (Minia Governorate). Group 3 included isolate No.5 isolated from Mallawy, (Minia Governorate) had similarity level $88.55 \%$ with the two groups mentioned before. Group 4 included isolate No.6 isolated from Behdal, (Minia Governorate) and isolate No.7 isolated from Elkasaseen, (Ismailia Governorate) with similarity level 96.82\%. Group 5 which included isolate No.8 isolated from Housh-essa, (Behera Governorate) with similarity level $93.06 \%$ with the isolates belonged to group 4 .

3.d. Evaluation of ten different tomato cultivars to infection by F. oxysporum f.sp. lycopersici isolated from El-Khatatba, (Minofiya Governorate) under greenhouse conditions:

Data presented in Table (5) clearly indicate that all tomato cultivars tested were liable to infection by the highly pathogenic isolate of the causal pathogen with different degrees. The highest average percentages of foliar yellowing and wilt $(43.5 \%)$ and vascular browning $(55.9 \%)$ were occurred in Super-Strain B cultivar. Meanwhile, Super-Marmand recorded the lowest average percentage in this respect, being $4.1 \%$ of foliar yellowing and wilt and $3.8 \%$ of vascular browning, respectively. Results (Table, 5) also indicate that it is possible to classify tomato cultivars tested into three different categories according to their response to infection by the agent tested. The first category included the relatively resistant cultivars, i.e. cvs. SuperMarmand, Marmand, Super-Shahd and Super-Balady. The second category included the relatively moderately resistant cultivars, i.e. cvs. Yara and Super-Magic. Meanwhile, the third category included the highly susceptible cultivars to infection (cvs. Super-Strain B, Prichard, Peto 95 and Fayrose). It is worthy to mention here that the disease symptoms were developed earlier on the highly susceptible cultivars than on the moderately or relatively resistant cultivars.

Table 5. Evaluation of ten different tomato cultivars to infection by F. oxysporum f.sp. lycopersici isolated from El-khatatba, (Minofiya Governorate) under greenhouse conditions

\begin{tabular}{|l|c|c|}
\hline \multirow{2}{*}{ Cultivar } & \multicolumn{2}{|c|}{ Disease severity (\%) } \\
\cline { 2 - 3 } & Foliar yellowing and wilt (\%) & Vascular browning (\%) \\
\hline Super-Strain B & 43.5 & 55.9 \\
\hline Prichard & 38.1 & 44.5 \\
\hline Super-Magic & 35.4 & 45.5 \\
\hline Peto 95 & 31.5 & 42.0 \\
\hline Yara & 24.7 & 39.2 \\
\hline Fayrose & 19.8 & 36.8 \\
\hline Super-Balady & 18.5 & 29.5 \\
\hline Super-Shahd & 11.2 & 22.2 \\
\hline Marmand & 7.5 & 17.0 \\
\hline Super Marmand & 4.1 & 3.8 \\
\hline Control & 0.0 & 0.0 \\
\hline Mean & 21.3 & 30.6 \\
\hline L.S.D at 0.05\% & 9.98 & 8.34 \\
\hline
\end{tabular}


3.e. Response of tomato seedlings of different ages to infection with the most virulent isolate of F. oxysporum f.sp. lycopersici:

This experiment was designed to study the effect of tomato seedling age on infection using the most virulent isolate of $F$. oxysporum f.sp. lycopersici on the susceptible cultivar (Super-Strain B) and the resistant one (Super-Marmand). Results in Table (6) indicate that, generally, plants grown from younger tomato seedlings were more susceptible to infection with the fungus than those developed from the older ones. Young seedlings (20 days old) were the most susceptible seedlings, followed by those of 25 and 30 days old, while 40 days old seedlings were the lowest susceptible ones. This was also true for the susceptible cultivar Super-Strain B. Similar trend was obtained with the relatively resistant cultivar Super-Marmand. Again, plants responded more positively by increasing age indicating that resistant was increased progressively by increasing age. Data also showed that there were significant differences among all tested plant ages on their reaction to the two tested cultivars, Super-Strain B and Super-Marmand. Additionally, the resistant cv. SupeMarmand responded more positively regarding its resistance to infection with the tested fungus.

Table 6. Response of tomato seedlings of different ages to infection with the most virulent isolate of $F$. oxysporum f.sp. lycopersici (El-khatatba) on the susceptible cultivar Super-Strain $B$ and the relatively resistant one Super- Marmand

\begin{tabular}{|c|c|c|c|c|}
\hline \multirow{3}{*}{$\begin{array}{c}\text { Tomato } \\
\text { age } \\
\text { (Days) }\end{array}$} & \multicolumn{4}{|c|}{ Disease severity (\%) } \\
\hline & \multicolumn{2}{|c|}{ Foliar yellowing and wilt (\%) } & \multicolumn{2}{|c|}{ Vascular browning (\%) } \\
\hline & $\begin{array}{c}\text { Susceptible (Super- } \\
\text { Strain B) }\end{array}$ & $\begin{array}{l}\text { Resistant (Super- } \\
\text { Marmand) }\end{array}$ & $\begin{array}{c}\text { Susceptible } \\
\text { (Super-Strain B) }\end{array}$ & $\begin{array}{l}\text { Resistant (Super- } \\
\text { Marmand) }\end{array}$ \\
\hline 20 days & 49.0 & 16.2 & 68.2 & 31.6 \\
\hline 25 days & 38.1 & 6.0 & 52.3 & 15.3 \\
\hline 30 days & 26.3 & 3.1 & 36.3 & 11.5 \\
\hline 40 days & 16.9 & 0.8 & 15.4 & 4.5 \\
\hline Control & 0.0 & 0.0 & 0.0 & 0.0 \\
\hline Mean & 26.1 & 5.2 & 34.4 & 12.6 \\
\hline $\begin{array}{l}\text { L.S.D at } \\
0.05 \%\end{array}$ & 12.30 & 6.99 & 18.66 & 7.48 \\
\hline
\end{tabular}

\section{D i s c u s s i on}

Over the last few years, tomato (lycopersicon esculentum Mill) wilt disease has become common and inflicted marked losses in yield in many Egyptian Governorates according to our field observations and complains of the vegetable growers. Natural infection recorded ranged from 14.3 to $37.5 \%$. These results agree with those reported before in Egypt and other parts of the world (Awad, 1990, Mariatt et al., 1996, Enespa and Dwivedi, 2014 and El-Mohamedy et al., 2014). Fusarium wilt caused by race of Fusarium oxysporum f.sp. lycopersici was sever in Arkansas and threatened to eliminate commercial tomato production in the state (Goode, 1966). During the course of this investigation, eight fungal isolates were 
isolated from the roots and stems of naturally infected wilted plants obtained from some Egyptian Governorates. The isolated fungi were identified and the most frequent was $F$. oxysporum according to the morphological, cultural characteristics and microscopic examination (Gilman, 1957, Booth, 1971, Barnett and Hunter, 1972, Barnett and Hunter, 1997, Palmer et al., 2010, Salehzadeh, 2012 and Mc Govern, 2015). In pathogenicity tests, the isolated eight fungal isolates caused wilt in some tomato cultivars similar to that obtained under, naturally infected conditions. Generally, all fungal isolates had the potentiality to infect tomato plants although they were varied in their pathogenicity from weakly to highly pathogenic.

Fusarium oxysporum f.sp. lycopersici has previously been reported to be main cause of tomato wilt in Egypt (El-Zawahry, 1984, El-Shami, 1987, Farag, 2011 and Sammour et al., 2013 and Radwan et al. 2016) and other parts of the world (Rodriguez et al., 2003, Song et al., 2004, Amini, 2009, Nijue et al., 2012, Jacobs et al., 2013, Enespa and Dwivedi, 2014 and Hamini-Kadar et al., 2014). Pathogenicity tests are the primary means to distinguish different pathogenic Fusarium strains, but they do not indicate whether isolates of a given physiologic race or forma speciales are genetically related (Katan et al., 1989). Some strains of $F$. oxysporum are responsible for vascular wilt disease of many plants of economical important and these strains show high level of host specificity and are classified on this basis into formae specials and races (Hirano and Aris, 2006 and El-Kazzaz et al. 2008). Several methods have been employed in the study of the genetics of specialized forms and races of $F$. oxysporum due to techniques based on the analysis of nucleic acids including random amplified polymorphic DNA (RAPD) (Boix-Ruiz, et al. 2015). However, host range studies revealed that the fungal isolates are specific in infection on solanceae species and it did not infect species from other plant families' i.e. Cucurbitaceae, leguminoseae, Chenopodiaceae and Graminae. Furthermore, symptoms produced by these isolates were typically of vascular wilt, caused by $F$. oxysporum since they produced symptoms spread up in the vascular bundles rapidly. No crown and root rot symptoms were obtained due to artificial inoculation of the aforementioned species and families. Therefore, these findings suggest that the fungal isolates under investigation are $F$. oxysporum f.sp. lycopersici (Jarvis and Shoemaker, 1978, Menzies et al., 1990 and Boix-Ruiz et al., 2015). Traditional criteria used to differentiate species of the fungus are based on plant host, colony appearance, morphological characteristics of the conidia and telemorph (Gordon and Martyn, 1997). Subsequently Woo et al, (1996) and Gordon and Martyn (1997) reported that $F$. oxysporum has about 80 formae speciales (i.e. pathotypes specific to species) and several subdivided into races (specific to cultivars within a species). Furthermore, classification should take into account some consistent characters added and described by Burgress et al, (1994) such as morphological characteristics, i.e. shape and mode of formation microconidia, presence or absence of chlamydospores, colony morphology and growth rate on PDA. Furthermore proper identifications of formae specials and races have significant application in the diagnoses of disease in addition to its importance in quarantine measures for plant materials (El-kazzaz et al. 2008, Gao and Zhang, 2013 and Mc Govern, 2015). 
In general, the obtained results from RAPD-PCR revealed that basically there were DNA variations among isolates of $F$. oxysporum f.sp. lycopersici isolated during this investigation. Regarding similarity, level, there is similarity among DNA of the pathogenic isolates isolated from different localities in the tested Governorates and affecting tomato plants. This similarity level was $85.43 \%$ among the tested isolates. However, dendrogram indicated that isolates might be divided into 5 main groups, i.e., group 1 that has similarity level accounted for 98.70 and includes two isolates from El-khatatba and Berket El-sabaa, (Minofiya Governorate). The second group has similarity level 96.89 and includes2 isolates from Sheben El-koam, (Minofiya Governorate) and isolate 4 from Derwa, (Minia Governorate). It is not surprising that isolate 1 and 3 have similarity level of 98.7, simply because they developed and revolutionized under the same environmental conditions and they are from the same native geographic origin but it is surprising that isolate two from Sheben El-koam, (Minofiya Governorate) and isolate four from Derwa, (Minia Governorate) had high similarity level of $96.89 \%$ although they were isolated from two localities belonging to two Governorates that remotely far from each other. This might be due to trade of seeds and movement of the pathogen between the two Governorates through seeds (El-Wakil et al., 1998, Reis et al., 2005, Sammour et al., 2013 and Mc govern, 2015). Group 3 included isolate No. 5 isolated from Mallawy (Minia Governorate) has similarity level of $88.55 \%$. This might be due to geographic origin of the isolates. Group 4 included isolate No. 6 isolated from Behdal (Minia Governorate) and isolate No. 7 isolated from El-kasaseen, (Ismailia Governorate) had similarity level $96.82 \%$ and this can be interpreted as above. Group 5 which included isolate No. 8 isolated from Housh-essa, (Beheira Governorate) had similarity level $93.06 \%$ recorded. Surprisingly, isolate 6 from Behdal and isolate 4 from Derwa, (Minia Governorate) and from Kasaseen, (Ismailia Governorate) have high similarity levels (96.89\%) with isolate 1 and 2 of El-khatatba and Berket El-sabaa, (Minofiya Governorate, 98.70\%) this may be due to trade of seeds and movement of pathogen through seeds.

In conclusion, the results obtained by RAPD-PCR showed variations in DNA levels (85.43) in the tested isolates of the pathogen and the possibility to separate the isolates into 5 groups. Grouping the isolates by RAPD-PCR was not related to virulence or geographic origin. However RAPD-PCR relatively was able to relate isolate 2 from El-Khatatba and isolate 3 from Berket El-sabaa, (Minofiya Governorate) to their origin to some extent. Such results obtained with RAPD-PCR are in line with results reported herein (Novack and Kohn, 1988, Saeed and AboElseoud, 1990, Lima and Menzes, 2002, Sallam, 2004 and Mohamed, 2010) who worked on other differentplant pathogenic fungi. Several methods have been employed in the study of the genetics of specialized forms and races of $F$. oxysporum due to techniques based on the analysis of nucleic acids including random amplified polymorphic DNA (RAPD) (Boix-Ruiz et al., 2015). The authors added and concluded that RAPD marker had only limited usefulness in correlating pathogenicity among the isolates and races. In contrary, Riveros et al. (2001) compared RAPD-PCR with classical, morphological and pathogenicity of Fusarium and found that the obtained results were inconsistent. 
In this study the tested cultivars under investigation showed variable responses to infection by the most virulent fungal isolate El-Khatatba (Minofiya Governorate) of F. oxysporum f.sp. lycopersici. Some proved highly susceptible such as Super-Strain B, Prichard, Peto 95 and Super-Magic; others were less susceptible to infection, such as Yara and Fayrose while, the remainders proved relatively resistant such as Super-Balady, Marmand, Super-Shahd and Super-Marmand. Results obtained in this investigation are in agreement with those found by many investigators in Egypt and other parts of the world (El-Zawahry, 1984; Moustafa and Khafagi, 1992; Moustafa, 1999; Rodriguez et al., 2003; Reis et al., 2005; Al-Khatib et al. (2006); Abdalla, 2007; Yousef, 2007; El- Kazzaz et al., 2008; Kapoor, 2008; Amini, 2009; Dordevic et al., 2012; Steinkellner et al., 2012 and Radwan et al., 2016). Moreover, the following Egyptian varieties and hybrids, i.e. Super red, Hybrid Zomoreda TH99806, V.F.N-8, Nema rock, Nema 1400, the local Hybrid Master 100 and Improved Saria were found relatively resistant to root-Knot nematode and hence may decrease infections with Fusarium wilt caused by $F$. oxysporum f.sp. lycopersici. Root-Knot nematode can induce susceptibility in normally resistant cultivars to Fusarium wilt fungi on host plant (Mai and Abawi, 1987 and France and Abawi, 1994). Subsequently, it has been reported that localization of the vascular infection is widely recognized as a primary resistant mechanism to Fusarium wilt in tomato plants and the distribution of the fungus is limited in resistant cultivars while extensive colonization occurs in susceptible ones (Rodriguez et al., 2003). Subsequently, it has been reported that most of the common varieties of tomato and bringal in heavily infested fields with Fusarium are susceptible and fungicides should be frequently used to control the disease (Kapoor, 2008).

Generally, percentage of disease index of Fusarium wilt was decreased progressively with increase of seedlings age and the older seedlings were more relatively less susceptible to infection than younger ones by the isolate tested (isolate El-khatatba). These results are partially in agreement with those reported by AlKhatib et al. (2006) and Amini (2009). It is reported that although has been an extremely useful characteristic virulence of $F$. oxysporum f.sp. lycopersici of differentiating between isolates of the fungus, it is still single traits since virulence has been shown to be influenced by number of factors including temperature, host range and method of inoculation (Kraft and Haglund, 1978; Williams, 1981; Hart and Endo, 1981; El-Kazzaz et al., 2008 and Steinkellner et al., 2012). On the other hand Steinkellner et al. (2012) found that infection by F. oxysporum f.sp. lycopersici on tomato varieties was not affected with plant age.

\section{A c know le d g m e n t}

The researchers are grateful to Prof. Dr. Kamel Abd Elsallam, PCR units, Agricultural Research Centre for his efforts in running RAPD-PCR for the isolates and constructive discussions. 


\section{$R$ e f e r e n e s}

Abdalla, O.A.M. 2007. Integrated control of tomato wilt disease caused by Fusarium oxysporum f.sp. lycopersici. M.Sc. Thesis, Faculty Agric., Assiut University, Egypt.

Abd-Elsalam, A.; Asran-Amal, K.A. and E.1-Samawaty, A. 2007.Isolation of high quality DNA from cotton and its fungal pathogens. J. Plant Diseases and Protection, 114: 113-116.

Al-Khatib, M.; Abu-Blan, H. and Masoud, S. 2006.Determination of resistance of locally grown tomato varieties to Fusarium oxysporum f.sp lycopersici in Jordan under greenhouse conditions. Jordan J. Agric. Sci., 2: 251-256.

Amini, J. 2009. Physiological race of Fusarium oxysporum f.sp. lycopersici in Kurdistan Province of Iran and reaction of some tomato cultivars to Race1 of Pathogen. Plant Pathol. J., 8(2): 68-73.

Awad, N.G.H. 1990. Studies on tomato wilt disease caused by Fusarium oxysporum f.sp lycopersici. Ph.D. Thesis, Fac. of Agric., Zagazig Univ., Egypt.

Bahar-Morid, Shahab-Hajmansoor and Nikoo-Kakvan 2012. Screening of resistance genes to Fusarium root rot and Fusarium wilt diseases in tomato (Lycopersicon esculentum) cultivars using RAPD and CAPs markers. Europ. J. Experimental Biol., 2 (4): 931- 939.

Barnett, H.L. and Hunter, B.B. 1972. Illustrated Genera of Imperfect Fungi. $2^{\text {nd }}$ Ed. Burgress Publishing Company, Mineoplis, USA. 241pp.

Barnett, H.L. and Hunter, B.B. 1997. Illustrated Genera of Imperfect Fungi. $3^{\text {nd }}$ Ed. Burgress Publishing Company, Mineoplis, USA. 241pp.

Booth, C. 1971. The Genus Fusarium. $2^{\text {nd }}$ Ed. Commonwealth Mycological Institute, Kew, Surrey, UK.

Booth, C. 1985. The Genus Fusarium. $2^{\text {nd }}$ Ed. Commonwealth Mycological Institute, Kew, Surrey, UK.

Boix-Ruiz, A.; Galvez-Paton, L.; Kara-Garcia, M.; Palmero-Lalmas, D.; CamachoFere, F. and Tello-Marqurna, J.C. 2015.Comparison of analytical techniques used to identify tomato-pathogenic strains of Fusarium oxysporum. Phytoparasitica, 43: 471-483.

Burgress, L.W.; Sammorell, B.A.; Bullock, S.; Gott, K.P. and Backhouse, D. 1994. Laboratory Manual for Fusarium Research. $3^{\text {rd }}$ Ed.. University of Sydney, Australia. 783pp.

Dhingra, O.D. and Sinclair J.B. 1995. Basic of Plant Pathology Methods. $2^{\text {nd }}$ Ed. Lewis Publication, Boca Raton. London. Tokyo.

Dordevic, M.; Vatchev, T.; Girejk, Z.; Sevic, M.; Zecevic; B.; Zdravkovic, J. and Ivanovic, M. 2012. Reaction of different tomato cultivars toward race 1 of Fusarium oxysporum f.sp. lycopersici. Genetika, 44: 109-118. 
El-Mohamedy, R.S.R.; Jubnoun-Khiareddine, H. and Daami-Renadi. M. 2014. Control of root rot diseases of tomato plants caused by Fusarium solani, Rhizoctonia solani and Sclerotium rolfsii using different chemical, plant resistance inducers.Tunisian J. Plant Protection, 9: 45-55.

El-Shami-Mona A. 1987.Solarizations in relation to Fusarium wilt of tomato in Egypt. Ph.D. Thesis, Fac. Agric., Ain Shams Univ., Egypt. 194pp.

El-Zawahry-Aida, M. 1984. Studies on Fusarium wilt of tomato. M.Sc. Thesis. Fac. Agric., Assiut Univ., Egypt. 107pp.

El-Kazzaz, M.K.; El-Fadly, G.B.; Hassan, M.A.A. and El-Kot, G.A.N. 2008. Identification of some Fusarium spp. using molecular biology techniques. Egypt. J. Phytopathol., 36: 57-69.

El-Wakil, M.A.; Abdoll, M.R. and Mathur, H.B.S.D. 1998. Fusarium oxysporum f.sp. lycopersici. Race 1 and Race 2 associated with tomato seed. Pakistan J. Biol. Sci., 11: 92-96.

Enespa and Dwivedi, S.K. 2014. Effectiveness of some antagonistic fungi and botanicals against Fusarium solani and Fusarium oxysporum f.sp. lycopersici infecting brinjal and tomato plants. Asian J. Plant Pathol., 8: 18-25.

Fakhouri, W. and Buchenaure, H. 2003. Characteristics of fluorescent Pseudomonad isolates toward controlling of tomato wilt caused by Fusarium oxysporum f.sp. lycopersici. J. Plant Dis. and Protect., 110: 143-156.

Farag-Hanaa, R.M. 2011. Effect of neem and willow aqueous extracts on Fusarium wilt disease in tomato seedlings: Induction of antioxidant defensive enzymes. Ann. Agric. Sci., 56: 1-7.

France, R.A. and Abawi, G.S. 1994. Interaction between Meloidogyne incognito and Fusarium oxysporum f.sp. phaseoli on selected bean genotypes. J. Nematology, 26: $467-474$.

Gabr, M.R.; Saleh, O.L.; Hussein, N.A. and Khalil, M.A. 1998. Physiological studies and cell-wall degrading enzymes of Fusarium oxysporum f.sp sesame and Macrophomina phaseolina: The causal organisms of wilt and root rot diseases of sesame. Egypt. J. Microbiol., 33: 595-610.

Gamal El-Din, I.F.; Ahmed, K.G.M. and El Fiki, A.L.L. 1982. Pathological effects of Exserohilum halodes (Drechsl) Leonard and Suggs and Ulociaolium botrytis Preuss, the casuals of tomato leaf spot disease in Egypt. Egypt. J. Phytopathol., 14: $107-120$.

Gao, R. and Zhang, J. 2013. Potential of DNA parcoding for detecting quarantine fungi. Phytopathology, 103: 1103-1107.

Geiser, DM.; Jimenez-Gasco, M.; Kang, S.; Makalowska, I.; Veeraraghavan, N.; Ward, TJ.; Zhang, N.; Kuldau, G.A. and O'Donnell, K. 2004. Fusarium ID v. 1.0: a DNA sequence database for identifying Fusarium. Europ. J. Plant Pathol, 110: 473-479. 
Gliman, J.C. 1957. A Manual of Soil Fungi. Iowa State Univ. Press., U.S.A. 450pp.

Goode, M.J. 1966. News race of tomato Fusarium wilt fungus. Arkansas Farm. Res., 15 (1): 12.

Gomez, K.A. and Gomez, A.A. 1984. Statistical Procedures for Agricultural Research. John Wiley and Son, Interscience Pub., New York, U.S.A., 678 pp.

Gordon, T.R. and Martyn, D. 1997. Population structure and the relationship between pathogen and non-pathogen strain of Fusarium oxysporum. Phytopathology, 87: 77-79.

Gothoskar, S.S.; Scheffer, R.P.; Walker, J.C. and Stahmann, M.A. 1953. The roles of pectic enzymes in Fusarium wilt of tomato. Phytopathology, 43: 535-536.

Hamini-Kadar, N.; Benaouili, H.; Benichou, S.; Kihal, M.; Benali, S. and Henni, J.E. 2014. In vitro effect of two fungicides on pathogenic fungi causing root rot on tomato in Algeria. African J. Agric. Res., 9: 2584-2587.

Hart, L.P. and Endo, R.M. 1981. The effect of length of exposure to inoculum plant age, root development and rot wounding on Fusarium yellows of celery. Phytopathology, 71: 77-79.

Hirano, Y. and Aris, T. 2006. PCR based differentiation of Fusarium oxysporum f.sp. lycopersici and radices-lycopersici and races of $F$. oxysporum f.sp. lycopersici. Japan Gen. Plant Pathol.,72: 273-283.

Irzykowska, I.; Bocianowski, J.; Waskiewicz, A.; Weber, Z.; Golinski, P.; Karolewski, Z.; Kostecki, M. and Irzykowski, W. 2012. Genetic variation of Fusarium oxysporum isolates forming fumonisin BI and moniliformin. J. Appl. Gen., 53: 237-247.

Jacobs, A.; Govender, R. and Van Heeerden, S. 2013. Fusarium oxysporum f.sp. lycopersici race3 causing tomato wilt in South Africa. Australian Plant Dis. Notes, 8: 145-147.

Jarvis, W.R. and Shoemaker, R.A. 1978. Taxonomic status of Fusarium oxysporum causing foot and root rot of tomato. J. Phytopathol., 68: 1679-1680.

Kapoor, A.S. 2008. Biocontrol potential of (Tricoderma spp.) against important of soil borne diseases of vegetable crops. Indian Phytopathol., 61: 492-498.

Katan, T.; Haar, E. and Katan, J. 1989. Vegetative compatibility of Fusarium oxysporum f.sp. dianthi from carnation in Israel. Plant Pathol., 38: 576-381.

Kraft, J.M. and Haglund, W.A. 1978. Reappraisal of the race classification of Fusarium oxysporum f.sp. pisi. Phytopathology, 68: 273-275.

Kordali, S. and Demirci, E. 1998. Fusarium species from various vegetables in Erzincan, Turkey. J. Turkish Phytopathol., 27 (2-3): 131-136. 
Lima, M.L.F. and Menzes, M. 2002.A comparative study of Collectotricium graminicola isolates by electrophoretic analysis of proteins and isozymes. Fitopatologia brasilleira, 27: 12-16.

Livens, B.; Rep, M. and Thomma, B.P.H.J. 2008.Recent developments in the molecular discrimination of formae specials of Fusarium oxysporum. Pest Management Science, 64: 781-788.

Mai, W.F. and Abawi, G.S. 1987. Interaction among root-knot nematode and Fusarium wilt fungi on host plants. Annu. Rev. Phytopathol., 25: 317-338.

Mariatt, M.L.; Correl, J.C.; Kaufmann, P. and Cooper, P.E. 1996. Two genetically distinct population of Fusarium oxysporum f.sp. lycopersici race 3 in the United States. Plant Dis., 80: 1336-1342.

Masunaga, T.; Shiomi, H. and Komada, H. 1998.Identification of race 3 of Fusarium oxysporum f.sp. radices-lycopersici. isolate from tomato in Fukuoka. Ann. Phytopathol. Soc., Japan, 64: 435.

Menzies, J.G.; Koch, C. and Seywerd, F.W. 1990. Additions to the host range of Fusarium oxysporum f.sp. radicis-lycopersici. Plant Dis., 74 (8): 569-572.

McGovern, R.I. 2015. Management of tomato disease caused by Fusarium oxysporum. Crop production, 73: 78-92.

Mohamed, A.M.S. 2010. Studies on Sclerotinia rot disease of common bean. M.Sc. Thesis. Fac. Agric., Assuit Univ., Egypt. 159pp.

Mohamed-Somaya A.A. 2007. Pathological studies on nematodes and fungi affecting vegetables in newly reclaimed soils. M.Sc. Thesis, Fac. Agric., Alex. Univ. $67 \mathrm{pp}$.

Mostafa, Y.M.M. 1999. Improving the productivity of tomato by producing F1 hybrids and using some antioxidants treatment. M.Sc. Thesis Horticulture (Vegetable crops). 124pp.

Mostafa, S.E.S. and Khafagi, Y.S. 1992. Reaction of certain tomato cultivars to Fusarium wilt and root rot Fusarium oxysporum f.sp. lycopersici and Rhizoctonia solani, respectively. Assiut J. Agric. Sci., 23: 199-207.

Nelson, P.E.; Toussoun, T.A. and Marasas, W.F.O. 1983. Fusarium species; An Illustrated Manual for Identification. Pennsylvania State Univ. Press, USA. 193p.

Nijue-Alice, W.; Njogu Eric, M.; Otaye Dan, O.; Cheplogoi Peter, K. and Omolo Josiah, O. 2012. In vitro inhibition of tomato Fusarium wilt causative agent by zearalenone from a soil inhabiting fungus. African J. Biotechnol, 11: $13683-13689$.

Novack, L.A. and Kohn, L.M. 1988. Electrophoresis of major proteins in stromata of members of Sclerotiniaceae. Trans. British Mycol. Soc., 91: 639-647. 
Nusret, O. and Steven, E.N. 2004. Fusarium crown and root rot of tomato and control methods. Plant Pathol. J., 3: 9-18.

Palmer, P.; Ozea, Vishal and Subramanian, R.P. 2010. Optimization of fusaric acid production by Fusarium oxysporum f.sp. radicis-lycopersici using response surface. J. Sci. and Technol., 3: 411-416.

Pushpa, K..; Borkar, G.M.; Patil, D.V. and Kamble, A.M. 1999. Studies on seed borne pathogens of pumpkin, cucumber, watermelon and muskmelon. J. Soils and Crops, 9 (2): 243-238.

Radwan, S.A.; Sameer-Kloud, A.; Abdel-Gawad, T.I.; El-Banna, A.A. and Galal, A.A. 2016. Fusarium oxysporum f.sp. lycopersici (FOL) race 1 and 3 as wilt incitant to tomato plants growing in El-Minia Governorate, Minia J. Agric. Res. and Develop., 36: In press.

Reis, A.H.; Costa, Poiteux L.S. and Lopes, C.A. 2005. First report of Fusarium oxysporum f.sp. lycopersici race 3 on tomato in Brazil. Fitopatologia Brasileira, 30: $426-428$.

Riveros, F.; Munoz, G.; Conzak, L.; Alvarez, M. and Hinrichsen, P. 2001. Comparison between DNA and morphological analysis for identification of Fusarium species isolated from muskmelon (Cucurbita melo L.). Agric. Technical, 61: 281-293.

Rodriguez-Molina, M.C.; Medina, L.M., Torres-Vila, L.M. and Cuartero, J. 2003. Vascular colonization patterns in susceptible and resistant tomato cultivars inoculated with Fusarium oxysporum f.sp. lycopersici races 0 and 1. Plant Pathol., 52: 199-203.

Rowe, R.C. 1980. Comparative pathogenicity and host ranges of Fusarium oxysporum isolates causing crown and root rot of greenhouse and field grown tomatoes in North America and Japan. Phytopathology, 70: 1143- 1148.

Saeed, F.A. and Abo-El Seoud, M.S. 1990. Comparative gel electrophoretic analysis of protein patterns of three pathogenic species of the genus Sclerotium. Assiut J. Agric. Sci., 21: 207-219.

Scott, J.W. and Jones, J.P. 1989. Monogenic resistance in tomato to Fusarium oxysporum f.sp. lycopersici race 3. Euphytica, 40: 49-53.

Salehzadeh, A. 2012. Interaction of polygalacturonase enzymes from Fusarium oxysporum with tomato polygalacturonase inhibiting protein. African J. Agric. Res., 7: 30-34.

Sallam-Nashwa M.A. 2004. Improvement of biological control of white rot of onion and varieties existed among the pathogen isolates. Ph.D. Thesis. Fac. Agric., Assiut Univ., 93pp.

Sammour, R.H.; Abdel-Momen, S.H. and Elagamey-Eman A. 2013. Genetic diversity among some isolates of Fusarium oxysporum f.sp. lycopersici from tomato plants in Egypt. Cell Biology, 2: 156-165. 
Song, W.; Zhou, L.; Yang, C.; Cao, X. and Liu, Z.X. 2004. Tomato Fusarium wilt and its chemical control strategies in hydroponic system. Crop Protection, 23: 243-247.

Steinkellner, S.; Hage-Ahmed, K.; Garrido-Garrido, J.M.; Illana, A.; Ocoampo, J.A. and Vierheiling, H. 2012. Acomparison of wild-type, old and modern tomato cultivars in the interaction with the arbuscular mycorrhizal fungus Glomus mosseae and the tomato pathogen Fusarium oxysporum f.sp. lycopersici. J. Mycorrhizal, 22: 189-194.

Woo, S.L.; Zoina, A.; Sorbo, G.; Lorito, M.D.; Scala, N.B.F. and Noviello, C. 1996. Characterization of Fusarium oxysporum f.sp. phaseali by pathogenic races VCGs. RFLPs and RAPD. Phytopathology, 86: 966-973.

Williams, P.H. 1981. Fusarium yellows. Pages: 124-129. In: Screening Crucifers for Multiple Disease Resistance. University of Wisconsin, USA.

Yan, M.; Li Ping, M.; Li Feng, A.; Zheng, P. and Sun, H.Q. 2004. Screening and initial identification of Fusarium spp. in cucumber [Chinese]. China Agric. Sci. Sichuan, China, 17 (3): 345-347.

Yousef-Sahar A. 2007. Evaluations of composted chicken manure Biocontrolling Fusarium wilt on tomato. Egypt. J. Phytopathol., 35: 61-72.

(Received 24/02/2016; in revised form 31/03/2016) 


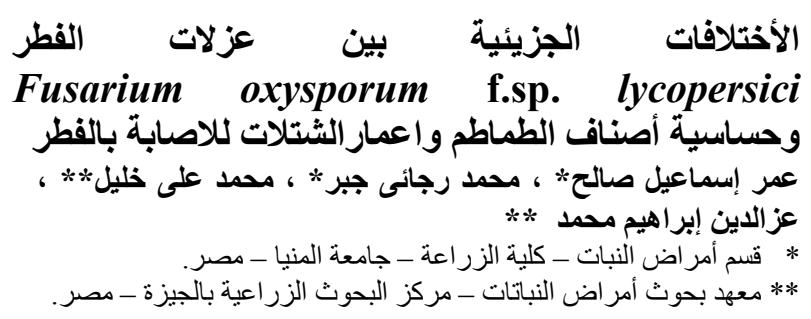

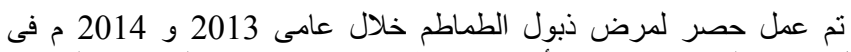

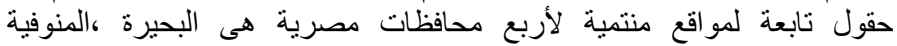

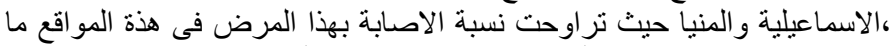

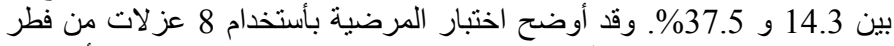

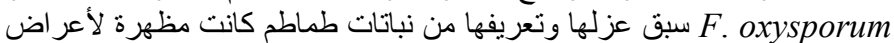

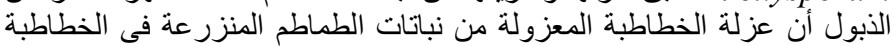

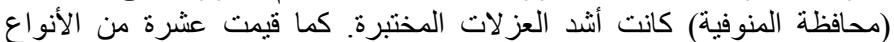

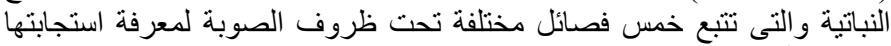

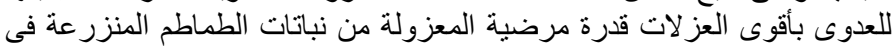

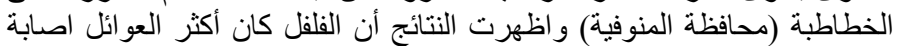

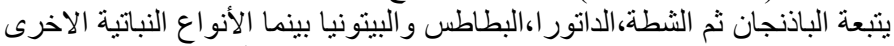

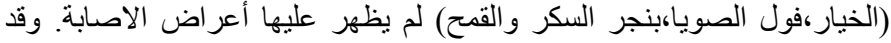

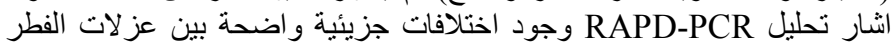

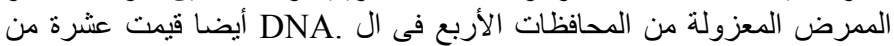

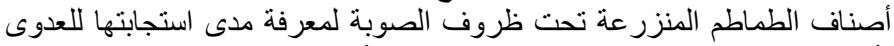

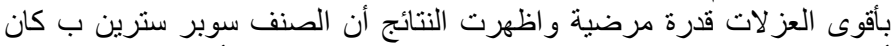

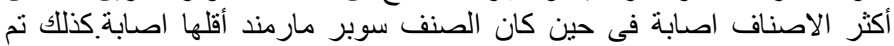

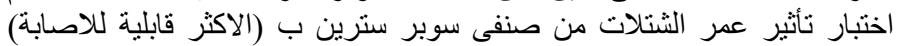

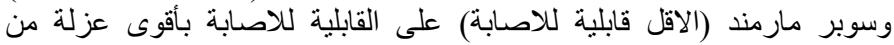

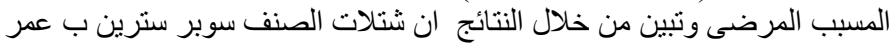

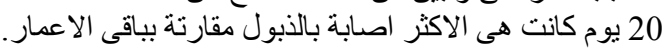

